\title{
THE SUCCESS OF ETHNICALLY BASED POLITICAL PARTIES: CASE OF SRI LANKA
}

\author{
N. Wijegoonawardana ${ }^{* 1}$ 《 iD \\ ${ }^{* 1}$ Department of History University of Colombo, Sri Lanka
}

DOI: https://doi.org/10.29121/granthaalayah.v8.i11.2020.1932

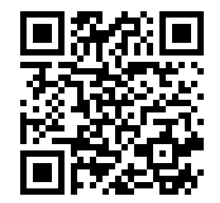

Article Type: Research Article

Article Citation: N.

Wijegoonawardana. (2020). THE

SUCCESS OF ETHNICALLY BASED

POLITICAL PARTIES: CASE OF SRI

LANKA. International Journal of

Research -GRANTHAALAYAH,

8(11), 153-163.

https://doi.org/10.29121/granthaa

layah.v8.i11.2020.1932

Received Date: 06 October 2020

Accepted Date: 30 November 2020

Keywords:

Political Parties

Ethnic Voting

Ethnic Conflict

Competitive Elections

Sri Lanka

\section{ABSTRACT}

Ethnic identities or policy interests; what influences the Sri Lankan voter the most? This analysis will be done providing particular attention to the case of Sri Lanka. The development in electoral outcomes in Sri Lanka provides an explicitly clear image of how, particular political parties obtain support from particular ethnic groups and in return serve the interest of particular groups. This study will be based on the results of the 1989 Parliamentary General Election and 2010 Parliamentary General Election samples, mainly in the North and East constituencies.

The Sri Lankan ethnic conflict offers an overview of the role of political parties and political actors in the competitive electoral system in relation to a conflicting situation. Therefore, this paper will examine as to how, such parties obtain support from particular ethnic groups and thereby safeguard the interest of those groups. Furthermore, this paper will seek to analyze how the, obtaining of moderate support from another ethnic group provides the best outcome but it is insufficient to divert from the interest of the group who provides the greatest support. Hence, this paper attempts at deciphering the main factor as to why it is harder for an ethnic party once established to become multi-ethnic.

\section{INTRODUCTION}

The comparative literature on mass electoral behavior can be viewed as a debate on the relative importance of social identities or economic interests (Lichbach and Zuckerman 1997). For advanced democracies, elections tend to take the form of a referendum on the economy, with voters rewarding or punishing mandatory political parties at the ballot box depending on their past policy performance (Lewis-Beck and Stegmaier 2000, Geys 2006). However, Horowitz (1985) noted that in an ethnically divided society, political parties obtain support from particular ethnic groups and in return serve the interest of such groups.

This paper will examine whether the pattern of Sri Lankan voters concur according to ethnic identities or economic policy-based interests? This study will be based on the results of the sample conducted from the 1989 Parliamentary General Election and 2010 Parliamentary General elections mainly north and east electoral districts. In addition to this, another aim of this research is to investigate how voting patterns are motivated by ethnic origin.

The politicization of ethnicity in Sri Lanka can be described as coinciding with the formation of political parties based on ethnic identity, or the ability of certain political parties to gain access to political and economic benefits by mobilizing ethnic constituencies. This was evidenced in the dissonance of interests that emerged in the 1920s

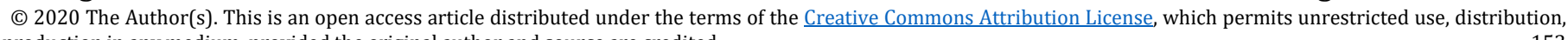
and reproduction in any medium, provided the original author and source are credited. 
amongst Sinhalese and Tamil ethnic leaderships which can be considered as the first appearance of an ethnocentric ideology. As demonstrated by trends of political mobilization (De Votta 2005), ethnicity has played a central role in Sri Lankan politics.

The debates on ethnic identities and mass electoral behavior can originate in the discipline of social science literature. Horowitz $(1985 ; 1991 ; 1993)$ proposes that, in an ethnically divided society, "voters will generally not cross ethnic lines" (1991c: 179), he also posits that, with a preferential ballot, at second or third preference, the voter might be willing to give support to moderate party from the other ethnic groups (1991c: 179).

Secondly, in Horowitz 's opinion, outside of their own ethnic group, political parties earn a stake in bidding for second or lower preferences. Parties might theoretically adopt more conciliatory or pragmatic approaches on ethnically divisive issues in order to gain such support. The way to induce politicians to be moderate is, electorally, to structure voting arrangements so that politicians have to rely, in part, on votes that are issued by members of a party other than their own. Such rewards are successful because, unless the candidates receiving them can be depicted as being moderate on inter-ethnic issues, those votes will not be forthcoming (1993: 24). Since moderate parties are seen as more likely than extremist parties to be able to obtain such cross-ethnic support, (Horowitz, 1991b, 452).

Thirdly, and similarly, moderate parties that cater to voters across the ethnic divide also obtain an opportunity to enter into preferential trade agreements with other parties, opening up not only the possibility for policy changes on historically contentious topics, but also creating direct incentives for cross-ethnic electoral alliances. "Intergroup accommodation and agreement are the price of good negotiations. Based on mutual compromises on ethnic issues, the sharing of second or third preferences is likely to lead to an accommodative inter-ethnic coalition if no group can form a government alone (Horowitz, 1991c: 189). To better understand the context in which Sri Lanka's most influential political parties work and what ethnic orientation each party has, a brief overview of the history of each important party will be given in this section.

\section{POLITICAL PARTIES FORMATION IN SRI LANKA}

The electoral history of Sri Lanka has consisted of several mainly contributory political parties from 1948 to the present era. The Sri Lankan Freedom Party (SLFP), Janatha Vimukthi Peramuna (JVP), Jathika Hela Urumaya (JHU), Mahajana Eksath Peramuna (MEP), Illankai Tamil Arasu Kachchi (ITAK), the Democratic People's Party of Eelam (EPDP), the Tamil National Alliance (TNA), and the Muslim Congress of Sri Lanka (SLMC)). An in-depth analysis of the bases for political party formation it becomes clear that below each party carries an ethnic ideology.

\section{Sri Lanka Freedom Party (SLFP)}

After the 1952 elections, the SLFP emerged as the new opposition to the UNP, and as its founder S.W.R.D. Bandaranaike asserted, as "a Middle Party between the UNP of the right and the Marxists of the left." However, the SLFP was in competition with Marxists who were certainly unprepared to yield anything to the newcomer by default. Then Bandaranaike formed the Mahajana Eksath Peramuna (MEP) with the Viplavakari Lanka Sama Samaja Party (VLSSP), which appealed to the majority of Sinhalese voters; this group came to be identified as the Pancha Maha Balavegaya: Sinhalese labourers, teachers, farmers, Ayurvedic physicians and Buddhist monks (Wickramasinghe 2006). Bandaranaike's policy, which brought him victory, was based largely on the recommendations of the report entitled "Betrayal of Buddhism," published by a committee of inquiry set up by the All Ceylon Buddhist Congress, which he had accepted publicly. One of the recommendations was the establishment of the Buddha Sasana Mandalaya for the care and enrichment of Buddhism. A 'Sinhala Buddhist' identity for the SLFP was thus promoted with the active participation of the Buddhist clergy (Wickramasinghe 2006:220). From the mid1950s, in alliance with the SLFP, some left parties had taken a more forceful anti-Christian, anti-Tamil and antiplantation Tamil position (Warnapala 2005). The March 1960 election was held at a time of communal clashes. It was a difficult time for the SLFP; the center-Left coalition disintegrated, and Bandaranaike was assassinated. de Silva (1981) states that it was evident to observers at the time that the LSSP was the larger of the two traditional Marxist parties, having a greater number of followers and an opportunity to strive towards national power. Since 1956 nationalism was based on religion and language, and in 1972 the first republican constitution was adopted by Mrs. Bandaranaike's government, marking a new era in the ethnic conflict. This era saw the promotion of linguistic nationalism by the Sinhalese, supported by a new political and institutional framework. As Uyangoda (2010) notes, 


\section{N. Wijegoonawardana}

the SLFP's social core was the non-Westernized economic and professional elite, but it also appealed to the rural electorate. Not until the 1990s, however, did the SLFP receive a significant vote from the ethnic minorities. The SLFP during the 1990s moved away from Sinhalese ethnic politics and adopted a multiethnic political platform, which it later rejected under new leadership in 2005. The SLFP, the leader of the United People's Freedom Alliance (UPFA), was able to gain power in the 2004 general elections, after which it responded to the ethnic issue by adopting a pluralist stance to engage in the peace process.

\section{United National Party (UNP)}

One of the two major political parties in Sri Lanka is the United National Party. The UNP is considered to have conservative policies that are right-leaning, pro-capitalist and liberal. The UNP was founded by the amalgamation of the three right-wing pro-dominion parties of the majority Sinhalese community and the Tamil and Muslim minority communities on September 6, 1946. It was founded by Don Stephen Senanayake, who was at the forefront of the UK independence struggle, having resigned from the Ceylon National Congress because he disagreed with the British Empire's revised objective of 'achieving freedom.' The business community and the landed gentry were represented by the UNP. Senanayake, however, also embraced populist policies that welcomed the party among the grassroots.

In the 1947 general election, the UNP campaigned to protect the traditional way of life and Buddhism, the religion followed by the majority of the people, from alleged communist threats from the left-wing opposition parties (the Lanka Sama Samaja Party and the Communist Party of Ceylon), on a platform of dominion under the United Kingdom. The UNP botched a working majority to win and paved an alliance with elements of Sinhalese and Tamil. In 1948, Ceylon became dominant, with D.S. The first prime minister was Senanayake. Much to the irritation of the Soviet Union, he pursued a pro-Western, anti-Communist foreign policy.

The new government ensued to marginalize the plantation workers of Indian origin, the Indian Tamils, using the Ceylon Citizenship Act of 1948 and the Parliamentary Elections Amendment Act of 1949. These initiatives were meant mainly to weaken the Left electorally.

In an accident in 1952, Prime Minister Senanayake died, and his son Dudley became Prime Minister. This irked S.W.R.D. Bandaranaike, the long-standing UNP stalwart, a Buddhist nationalist leader known for his center-left views. To establish the Sri Lanka Freedom Party (SLFP) as a balancing force between the UNP and the Marxist groups, Bandaranaike left the party.

The UNP tried to reduce the ration of rice in 1953, which resulted in Dudley Senanayake having to resign. His nephew, Major John Kotelawala, succeeded him. Mostly because of its support of minority religious groups, especially because of its support for minority religious groups, there was increasing disagreement with the UNP. To the consternation of the mainly Buddhist Sinhalese, Catholics. In the 1956 elections, Bandaranaike was able to take advantage and lead the SLFP to victory. Soon after, the infamous Sinhala Only Act was passed, leading to communal clashes in 1958. When the UNP organized a 'March on Kandy', an attempt at a language agreement with the Tamil Federal Party was thwarted.

In 1965, in coalition with the Mahajana Eksath Peramuna, the Tamil ethnic Federal Party under Dudley Senanayake, the UNP came to power again in 1965, but it lost to the SLFP in a 1970 landslide, which had formed an electoral alliance with Marxist parties known as the United Front.

The UNP was the leading member of the United National Front coalition, which won 37.8 percent of the popular vote and 82 out of 225 seats in Parliament, in the last legislative elections in Sri Lanka on 2 April 2004.From December 2001 until April 2004, when it had 109 seats, the Front had previously retained a majority in parliament, with Ranil Wickremesinghe as prime minister. From 1947 to 1956, from 1965 to 1970 and from 1977 to 1994, the UNP was previously the ruling party or in the governing coalition. In total, for 33 out of 57 years of its independent existence, the UNP ruled Sri Lanka (formerly known as Ceylon). From the establishment of the presidency in 1978 to 1994, the UNP also had oversight of the executive presidency.

During the period 2002-2005, the UNP set out the criteria to be followed by the parties during negotiations with the LTTE in order to pursue solutions to ethnic conflicts in Sri Lanka.

\section{Janatha Vimukthi Peramuna (JVP)}

The JVP emerged as a new left organization in 1969 under the leadership of Rohana Wijeweera, drawing university students and young men from non-elite Sinhalese backgrounds. Wickramasinghe (2006) notes that while forming the radical alternative to the UNP, the JVP caused the overturn of the left by radical youth in the South, 
leading two violent insurrections that were associated with the Dharmapalite anti-imperialist monks of the Vidyalankara Pirivena of the 1940s and their ideological students. These developments changed the position of Buddhist monks in politics in the next decades from being bearers of Marxist ideals in the late 1940s and has been described as the "flowering and the destruction of the social movement" (Wickramasinghe 2006: 234). However, in the late 1970s the JVP joined the mainstream. The party first received international recognition in 1971 when it launched an abortive insurrection. It was later banned as a party by President J.R. Jayewardene after the 1983 antiTamil riots. de Silva (1986) highlights that the JVP initially showed sympathy towards Tamils and even claimed that the Tamil rebels were fighting against the same opposition. However, when conditions turned unfavorable the party changed its ideology to a nationalistic stance to ensure its survival. It strongly opposed the 1987 Indo-Lanka Accord, and again attempted to obtain power by means of force, this time to greater effect since it was better prepared and more deeply rooted. The human cost of this encounter was also greater. Despite its near success in late 1988 it was rapidly destroyed in 1989 by President Premadasa. However, by 1994 the JVP had revived and re-entered mainstream politics. It won 10 seats in the October 2000 parliamentary elections and 16 seats in the December 2001 elections. The party performed best in the April 2004 parliamentary elections, winning 39 seats, and entered as part of the United People's Freedom Alliance. It opposed attempts to accommodate minorities, devolve power and negotiate settlements (De Votta 2007). Venugopal (2010) notes that the JVP's consistent and unrestrained opposition to the government on peace reform allowed it to place constraints on the development of the negotiation process.

\section{Jathika Hela Urumaya (JHU)}

The JHU first sought legal validation through the means of the Sihala Urumaya (SU) during the run-up to the 2004 elections. To achieve this, the JHU signed a memorandum of understanding with the Sihala Urumaya, stating that only the Buddhist monks in the party would contest the election. The political connection between the two parties was perceived with scepticism by the voting public due to the lack in transparency. The JHU over time showed a similar ideology to that of the Sihala Urumaya; for example, Tamil politicians and opportunistic Sinhalese politicians were viewed by both parties as potential threats, since they had significant foreign support. Furthermore, the JHU accused Sinhalese politicians of corruption. The JHU is considered to be a response to the marginalization of monks in political decision making at the national level, and its objective to be the establishment of a dharma raja, a Buddhist state. ${ }^{1}$ The JHU believes that Buddhism is in danger in a country where it should be protected, and that the peace process is a threat to Buddhism and Buddhists in Sri Lanka. The anti-colonialism of the JHU is seen in the image of Norway as a colonial power. During the April 2004 elections the Venerable Athuraliye Rathana, JHU media spokesman, remarked: "the Sangha has entered the arena of politics to ensure the protection of Buddhist heritage and values which had been undermined for centuries" (Daily Mirror, 19 February 2004). There were several contributory factors to the JHU ideology of a Buddhist state, relating to fear of the LTTE claim for Eelam, the power struggle between the two main parties putting the country in a politically unstable position, and the increase in the number of conversions of Buddhists and Hindus to Christianity (Deegalle 2004).

\section{Mahajana Eksath Peramuna (MEP)}

Established in 1956, the Mahajana Eksath Peramuna (MEP) was an electoral alliance. It consisted of the SLFP led by S.W.R.D. Bandaranaike, Philip Gunawardena led by VLSSP, and Wijeyananda Dahanayake led by Sinhala Bhasha Peramuna. In the 1956 elections, this coalition won and formed the government. An occurrence that reshaped power relations in post-colonial Sri Lanka was the emergence of the MEP coalition and its electoral success in 1956. Sinhalese nationalist in ideological and cultural guarantees was this newly established alliance of political parties (Uyangoda 2010). After Philip Gunawardena and William de Silva resigned from the cabinet, the MEP alliance collapsed in May 1959. Joining the opposition was the VLSSP. Philip Gunawardena, who formed a new political party in 1959, adopted the name Mahajana Eksath Peramuna. Philip Gunawardena and PH William Silva, on the basis of the principles of the earlier MEP, formed the MEP. The MEP won 10 parliamentary seats during the March 1960 General Election. The party merged with the LSSP and the CP to form the United Left Front in the 1960s. Dinesh Gunawardena, the leader of the MEP, became one of the eight opposition members of the Sri Lankan Parliament in 1983. In 1989, under the new proportional representation electoral structure, the MEP battled alone and took three out of 225 parliamentary seats. In 2000, the MEP became one of the constituent members of the People's Coalition,

\footnotetext{
${ }^{1} \mathrm{JHU}$ manifesto to restore Buddhasasana, available at http:// www.srilankaelections.com/manisfesto/JHU-EngManifesto.html.
} International Journal of Research -GRANTHAALAYAH 


\section{N. Wijegoonawardana}

which had three parliamentary leaders. The MEP declined to accept the P-TOMS stipulations in 2005 . The counterpoint to the MEP was its essential function.

\section{Sri Lanka Muslim Congress (SLMC)}

The founding of the SLMC in 1986 was the result of the rise of Muslim identity politics, arguing that Muslims' political interests differed greatly from those of the Tamil community. Knoerzer (1988) states that a central development in Muslim mobilization for regional autonomy was the establishment of the SLMC. The party leaders stressed that it would have a negative impact on Muslim interests to pursue the secessionist ideology of the Tamils. Uyangoda (2002) states that, instead of joining an armed struggle waged by Tamil nationalist forces, Muslims needed to create a political party to serve their interests through negotiation and cooperation with the Sinhalese political leadership. The proposed ethnic conflict solution established in the late 1980s also had to resolve the SLMC's demand for Muslim regional autonomy as an integral component of the negotiated settlement. This was evident on two occasions: the first was the PSC, founded in the 1990s to create a conflict resolution mechanism, and the second was the peace process between 2002 and 2005.

\section{Illankai Tamil Arasu Kachchi (ITAK)}

Illankai Tamil Arasu Kachchi (ITAK) is a political party from Sri Lanka representing the ethnic Sri Lankan Tamil community. It was formed in 1949 as the All Ceylon Tamil Congress' (ACTC) breakaway group. ITAK merged with the ACTC and the Ceylon Workers' Congress (CWC) in 1972 to form the United Tamil Front, which later changed its name to the United Tamil Liberation Front (TULF). ITAK remained largely inactive until 2004, when the TULF split resulted in the re-establishment of ITAK as an active political party. The Tamil National Alliance is now a constituent party of ITAK.

\section{Eelam People's Democratic Party (EPDP)}

The Eelam People's Democratic Party (EPDP) is headed by Douglas Devananda, its chairman. Douglas Devananda was one of the founding members of the Eelam Revolutionary Student Organization (EROS), one of the earliest Tamil militant organizations in Sri Lanka. EROS split into two in 1980, leading to the creation of the Eelam Revolutionary Liberation Front of the People (EPRLF). There were disputes between Devananda and Padmanaba, the political leader of the EPRLF, towards the beginning of 1986. The leadership of the EPRLF broke up into two factions. The EPRLF faction (Douglas) formally split from the EPRLF in 1987. With the collaboration of the faction of the People's Liberation Organization (PLO) of Tamil Eelam led by Paranthan Rajan, Douglas Devananda then formed the Eelam National Democratic Liberation Front (ENDLF). The When Paranthan Rajan began working with Indians, the ENDLF collapsed Douglas Devananda Devananda was opposed to the Indian intervention in the ethnic conflict in Sri Lanka.

\section{Tamil National Alliance (TNA)}

A political alliance representing the Sri Lankan Tamil minority of the country is the Tamil National Alliance. It was formed by a group of moderate Tamil nationalist parties and former militant groups in October 2001. It reinforced discussions to resolve the ethnic conflict in Sri Lanka with the rebel Liberation Tigers of Tamil Eelam (LTTE). However, since the end of the civil war and the defeat of the LTTE, the ultimatum for an independent state was released by TNA. During its existence, the TNA and its supporters have been subjected to numerous attacks and three of its sitting members of Parliament have been murdered, allegedly by government-backed groups. The TNA currently consists of four parties: the Revolutionary Liberation Front of the Eelam People, Illankai Tamil Arasu Kachchi, the Tamil Eelam People's Liberation Organization and the Liberation Organization of Tamil Eelam. In the national parliament, the TNA currently has 16 members. In the Northern Province, it controls the provincial government and forms part of the provincial government in the Eastern Province. It also controls, in the north and east, 33 local authorities.

\section{DATA ANALYSIS}

This section aims at examining the elections results from the years 1989-2010 in order to identify voting patterns. The sample was taken only from 1989 general elections and the 2010 parliamentary elections in the north 
and east electoral districts because this study treats 1989 as the peak of the ethnic conflict and 2010 as the defeat of the LTTE by the Sri Lankan government through military victory. This paper aims at analyzing the results of the general elections of 1989 and 2010 through graphical representation.

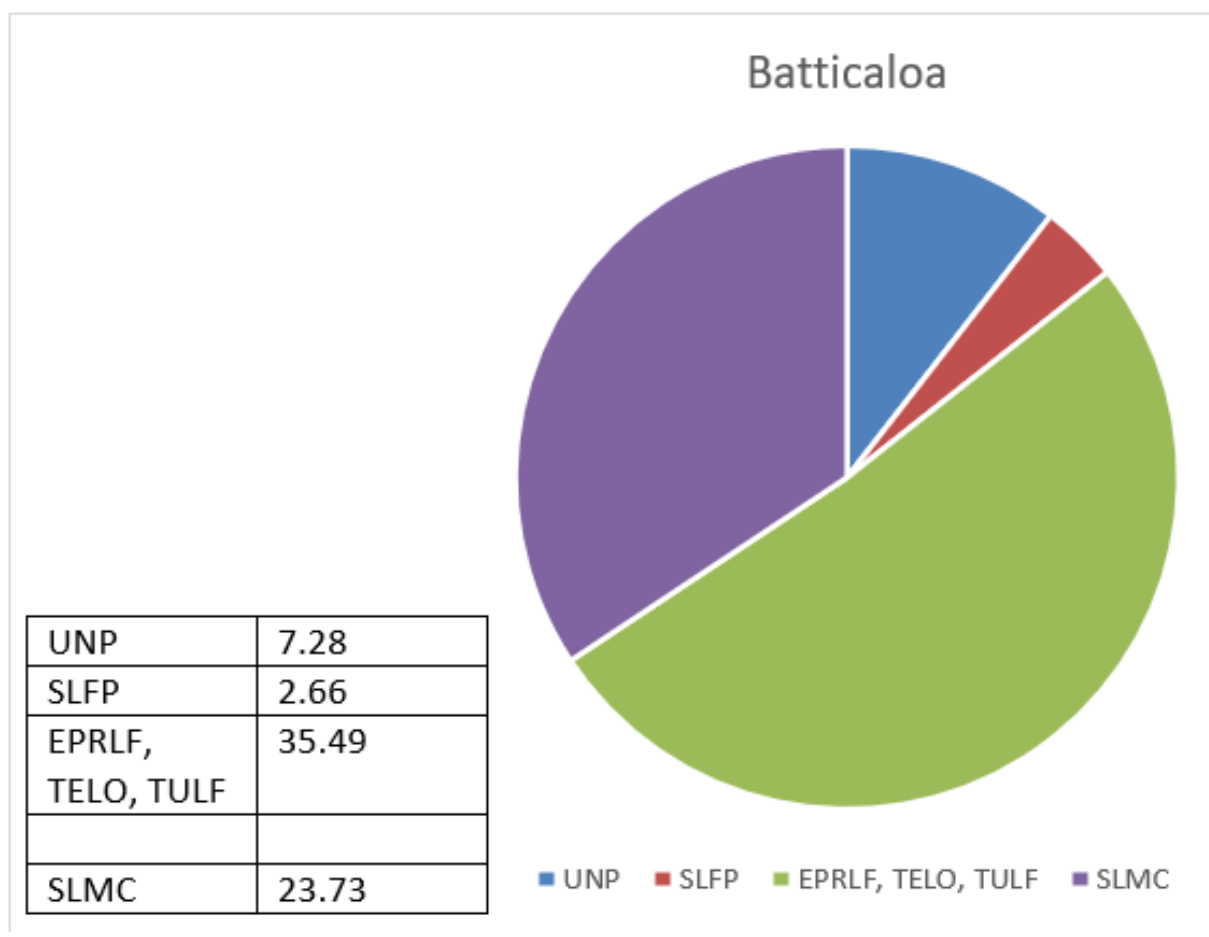

Chart 1:1989 Source: Department of Election

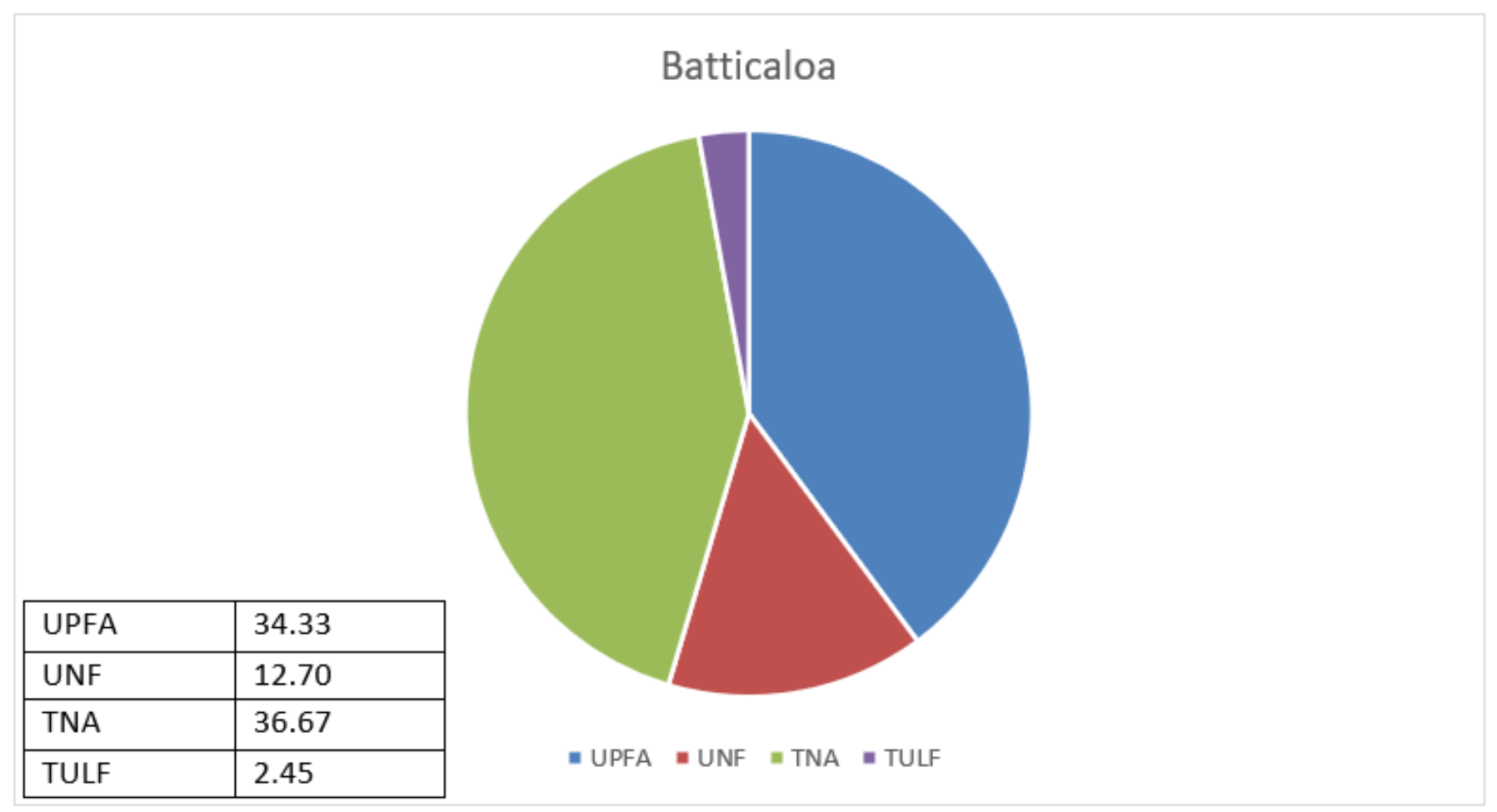

Chart 1.1: 2010 -Source: Department of Election 


\section{N. Wijegoonawardana}

Chart one depicts the percentage results for the Batticaloa district in 1989, where the UNP achieved 7.28\% whilst the SLFP had gained $2.66 \%$ and the largest electoral victory was won by coalition of the TULF with the EPRLF and the TELO with a total of $35.49 \%$. The SLMC was able to win $23.73 \%$ of the votes. In comparison to this in the 2010 general elections depicted in Chart1.1 the UPFA (the coalition of the SLFP, JVP, SLMP, MNUA, MEP, DUNF and the DVJP) won $34.33 \%$ of the votes whereas the UNF won $12.7 \%$, the TNA $36.67 \%$ and the TULF won $2.45 \%$. The Statistic Department of Sri Lanka in a survey conducted in the year 2001 as represented in chart 1.2 reports that the Batticaloa district is comprised of a Sinhala Population of only $1.3 \%$ whereas the Tamil population comprises of over 74.5\% and the Sri Lanka Moor Population filling the rest amounting to 23.5\%. The UNP, SLFP and the UPFA are predominantly Sinhalese parties whereas the TULF and TNA are largely Tamil dominant parties.

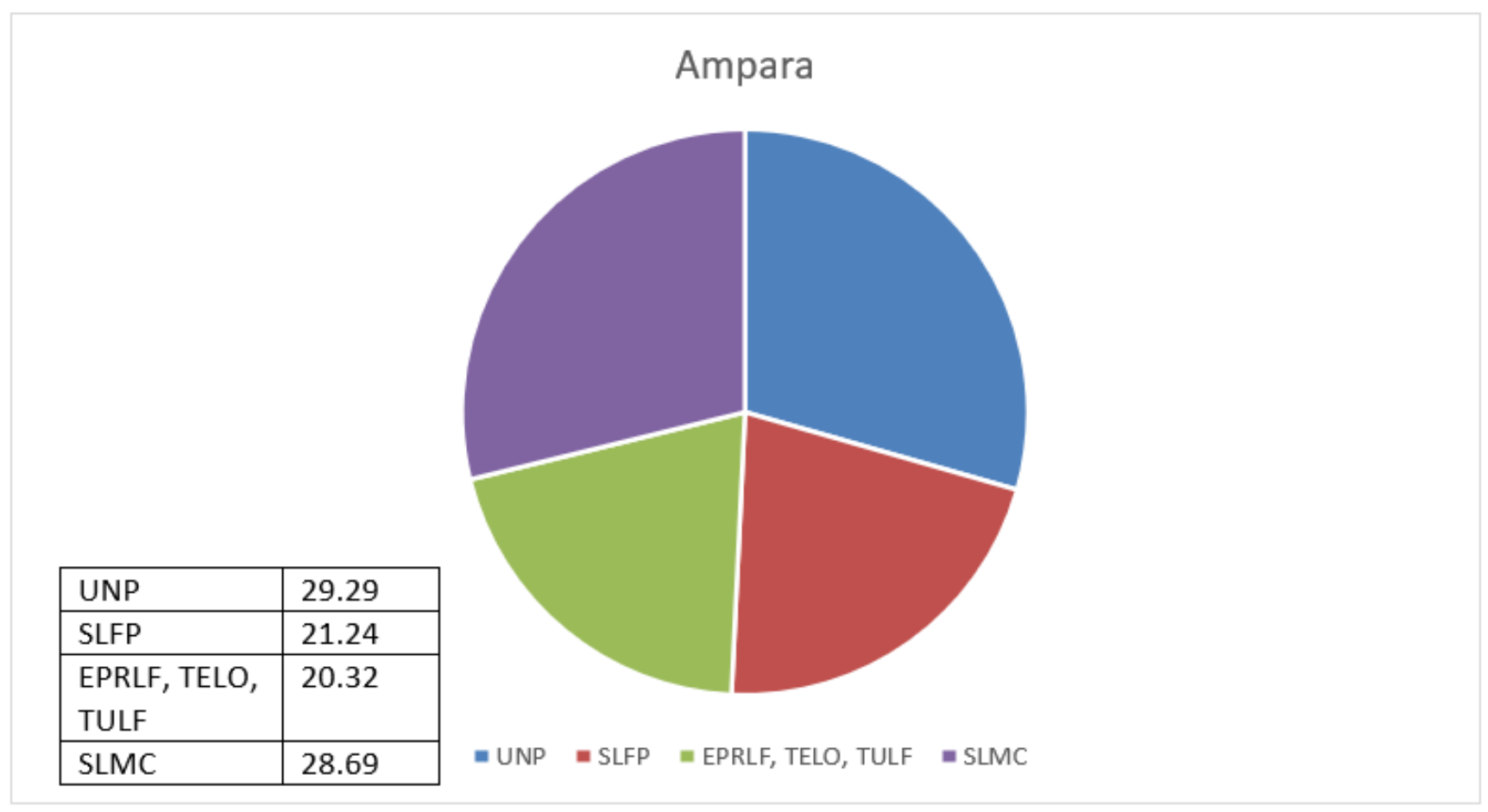

Chart 2: 1989- Source: Department of Election

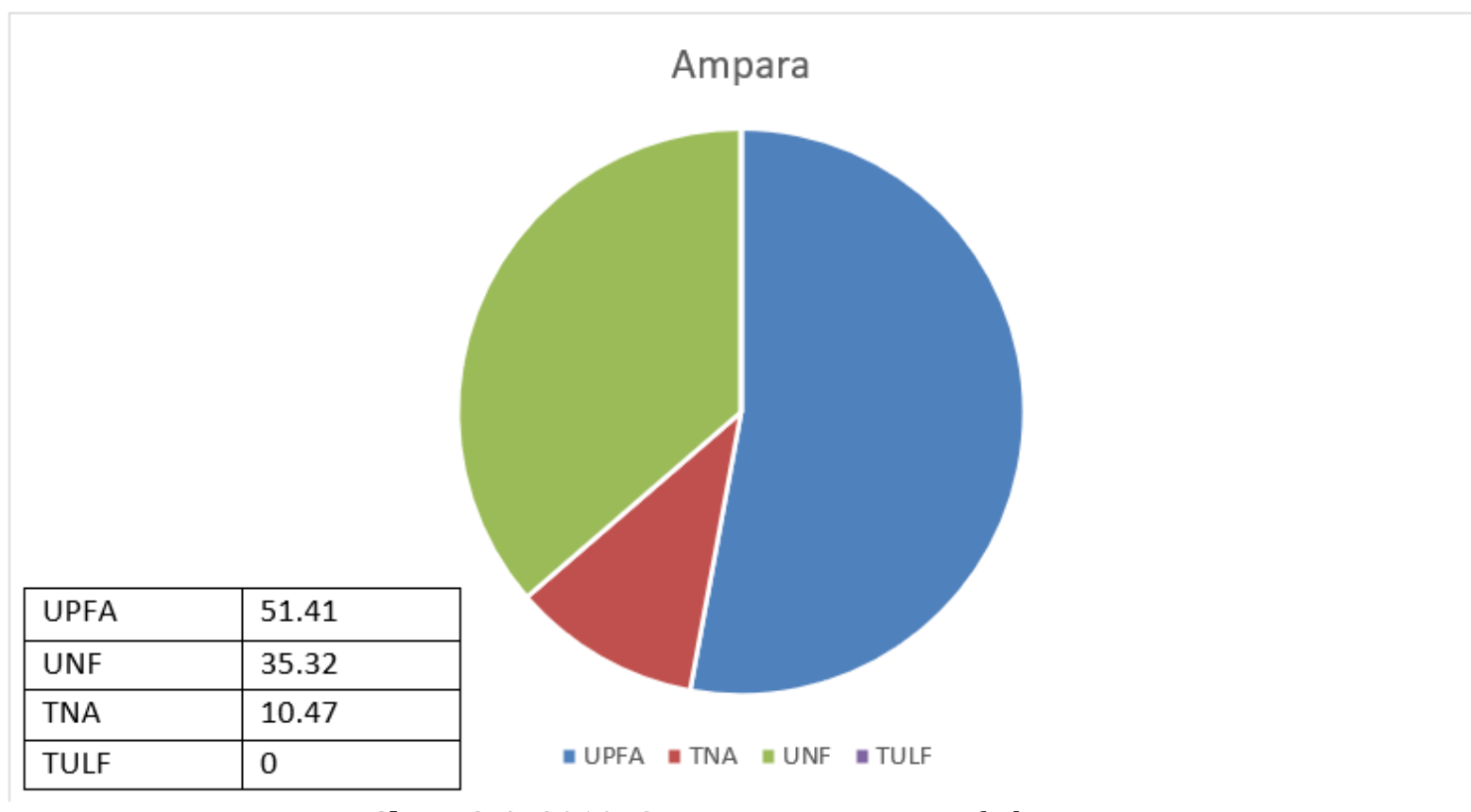

Chart 2.1: 2010- Source: Department of Election 
Chart two illustrates the electoral results of the Ampara district in the year 1989, where the UNP and SLEP won $29.29 \%$ and $21.24 \%$ respectively. The TULF achieved $20.23 \%$ and the SLMC won $28.69 \%$ of the votes. Chart 2.1 illustrates the electoral results of the same district in the year 2010, where the UPFA won 51.41\%, the UNF won $35.32 \%$ and the TNA won $10.47 \%$ whilst the TULF won no votes. The Statistical department reveals that the Sinhalese population in the Ampara district consist of 39.9\% whilst the Sri Lankan Tamils comprise of only 18.4\% and the Sri Lanka Moor population is entailed in Ampara district at 41.3\%.

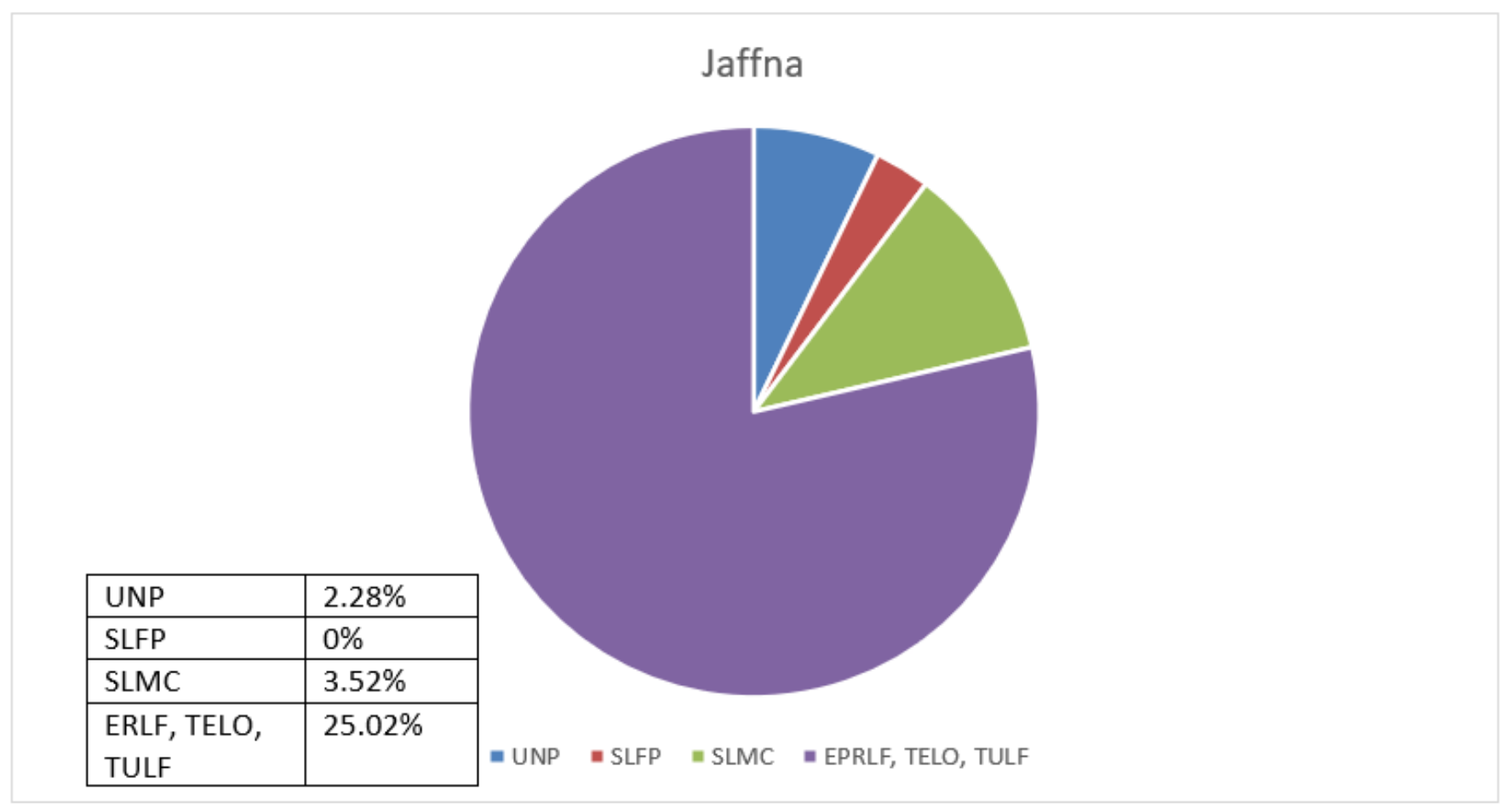

Chart 3: 1989- Source: Department of Election

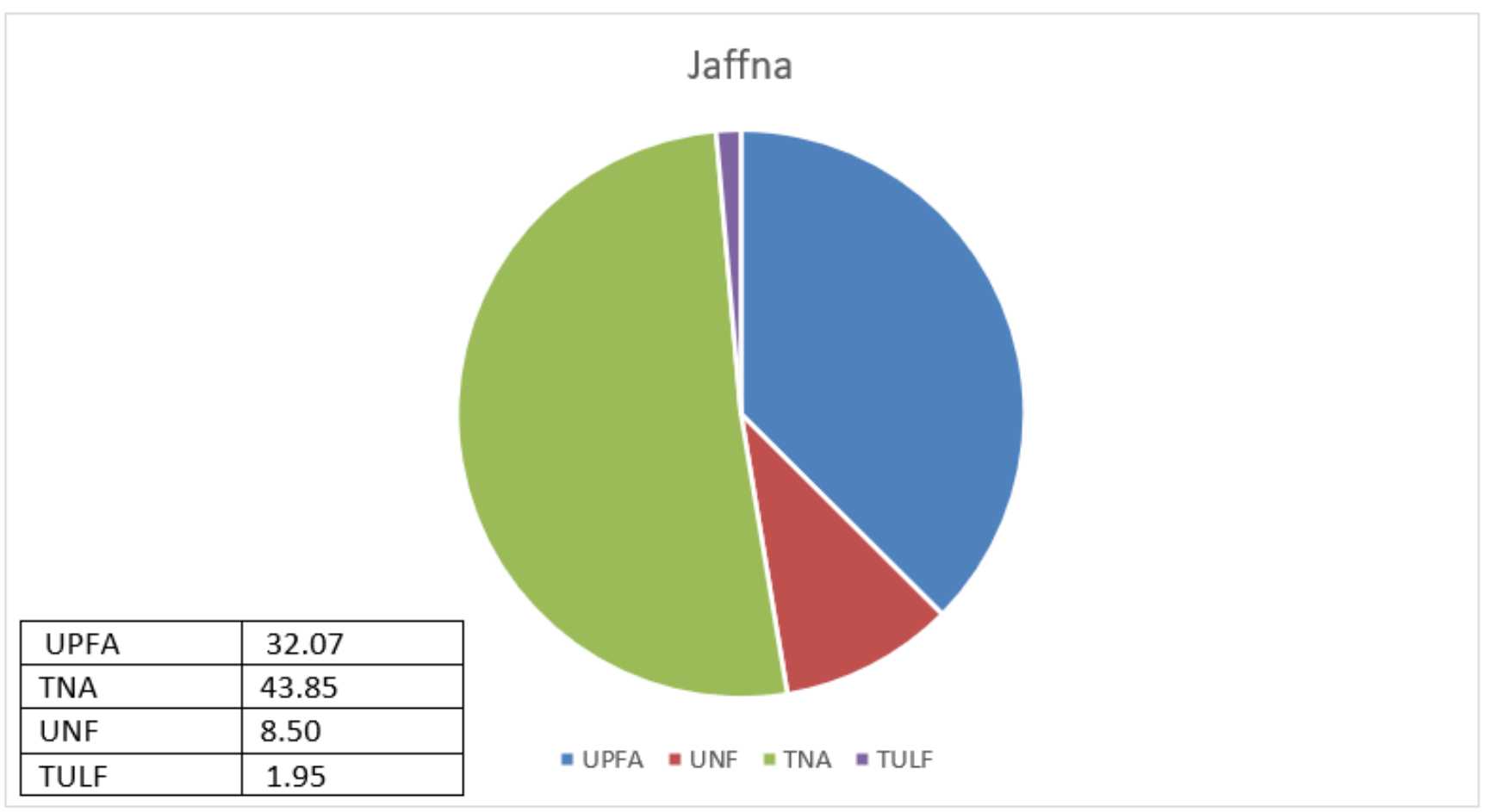

Chart 3.1: 2010- Source: Department of Election 


\section{N. Wijegoonawardana}

Chart three depicts election results of the Jaffna district during the elections of 1989 where the UNP won 2.28\% the TULF won $25.02 \%$ percent, the SLMC won $3.52 \%$ and the SLFP winning 0 votes. In comparison to this when considering chart 3.1 illustrating the election results of the 2010 general elections the UPFA won $32.07 \%$ the TNA won $43.85 \%$ the UNF won $8.50 \%$ and finally the TULF won $1.95 \%$ of the votes. In accordance with this the survey conducted in 2001 by the statistics department reveals that the lowest percentages of Sinhalese population are reported from districts of Northern Province with only 4.8\% whilst the Sri Lankan Tamils highest population of 93.7\% resides in the Northern Province and Sri Lanka Moor population being only 1.1\%.

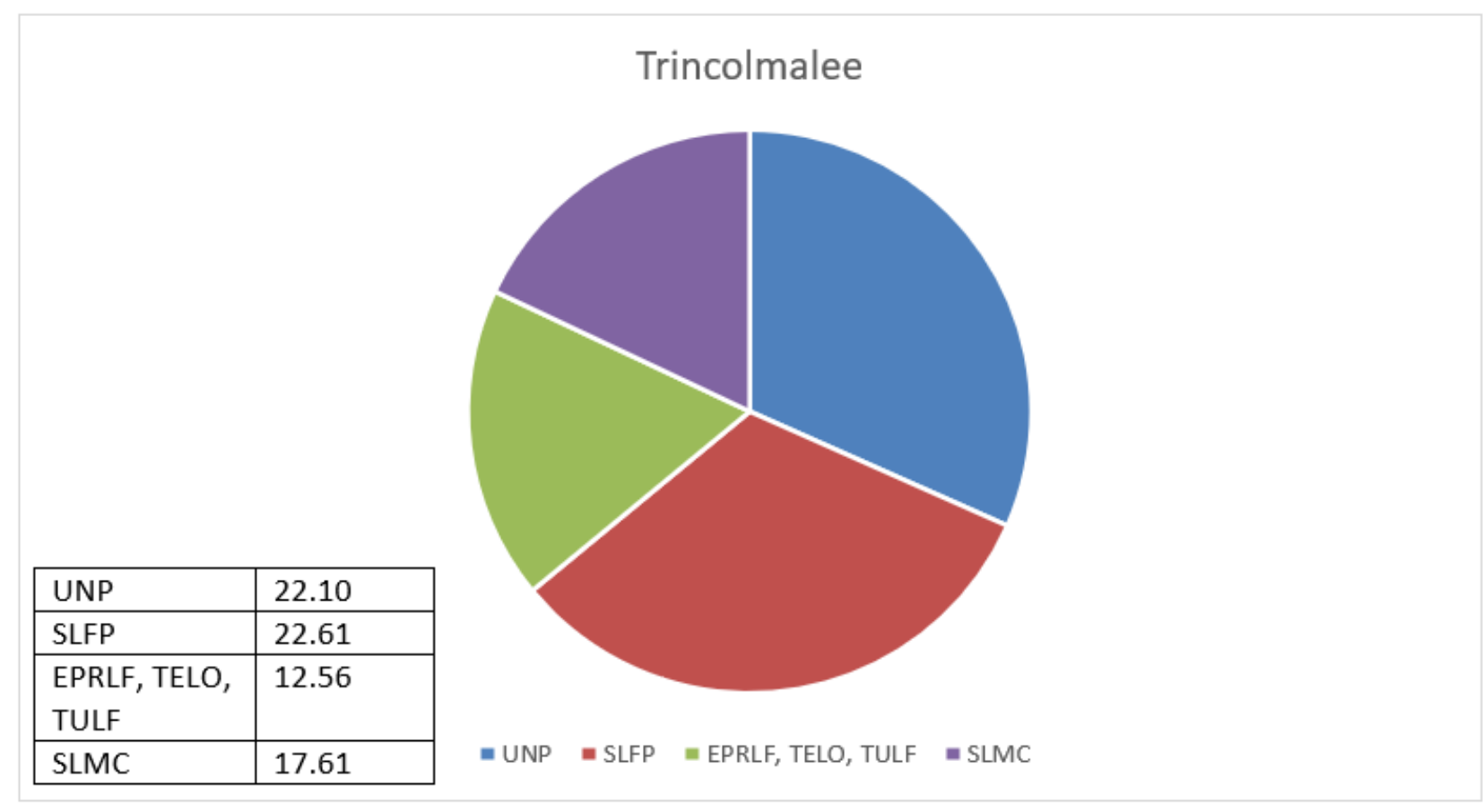

Chart 4: 1989- Source: Department of Election

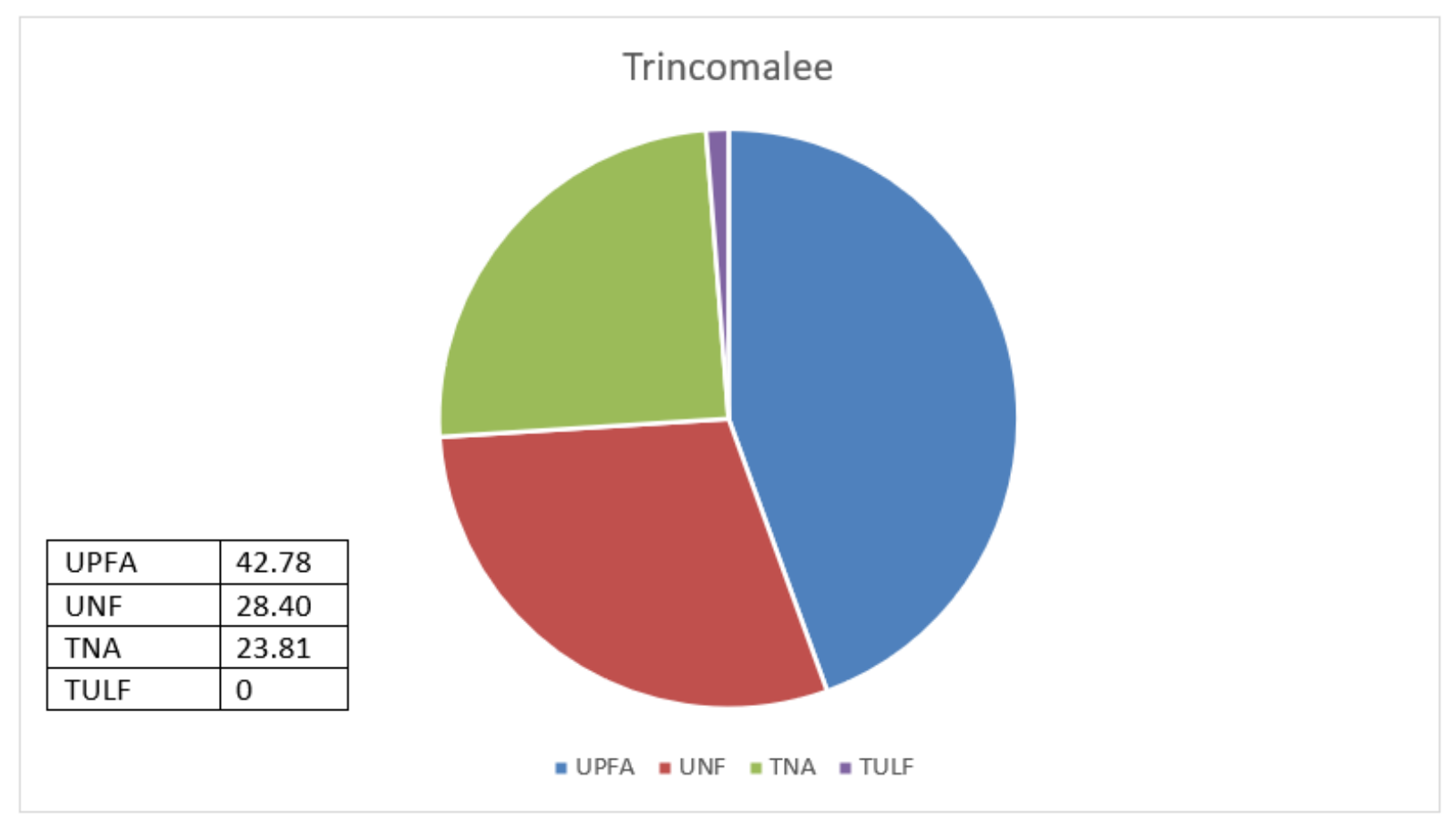

Chart 4.1: 2010- Source: Department of Election 
Chart four exhibits the Trincomalee district's election results for the year 1989 where the UNP attained a $22.10 \%$ of the votes and the SLFP won $22.21 \%$ the TULF won a total of $12.56 \%$ and finally the SLMC won a total of $17.61 \%$ of the votes. Chart 4.1 graphically represents the 2010 election results in which the UPFA won $42.78 \%$ the UNF won $28.40 \%$, the TNA won $23.81 \%$ and the TULF won 0 votes. The Sinhalese population of the Trincomalee district amounts to $23.4 \%$ whilst the Sri Lankan Tamils population totals to $48 \%$ the Sri Lanka Moor population amounts to $28.2 \%$.

\section{CONCLUSION}

Analyzing the above presented data, it can be concluded that the Sri Lankan voting behavior presents a pattern of an ethnically divided society since the election results portrays an image of voters who are unwilling to cross ethnic lines. It also shows that when voters are presented with a preferential ballot they tend to show support towards a moderate party from the ethnic group which can be clearly deciphered through the election results for the coalition of the TULF with the EPRLF and the TELO as well as the TNA coalition party. Therefore, in conclusion it can be stated that Sri Lankan voters who have experienced an ethnic conflict have been voting along the lines of ethnic origin rather than economic policy interests presented by the political parties. This is characteristic of an ethnically divided society in which political parties obtain support from particular ethnic groups and in return serve the interests of such groups.

\section{SOURCES OF FUNDING}

This research received no specific grant from any funding agency in the public, commercial, or not-for-profit sectors.

\section{CONFLICT OF INTEREST}

The author have declared that no competing interests exist.

\section{ACKNOWLEDGMENT}

None.

\section{REFERENCES}

[1] Chandra, K. (2003). Why Ethnic Parties Succeed: Patronage and Ethnic Head Counts in India. New York: Cambridge University Press.

[2] de Silva, K. M. (1986). Managing Ethnic Tensions in Multi-Ethnic Societies Sri Lanka 1880- 1986. Colombo: University Press.

[3] De Votta, N. (2005). From Ethnic Outbidding to Ethnic Conflict: The Institutional Bases for Sri Lanka's Separatist War. Nations and Nationalism, 141-159.

[4] Geys, B. (2006). “Explaining Voter Turnout: A Review of Aggregate-Level Research.” . Electoral Studies, 637663.

[5] Horowitz, D. (1991c). A Democratic South Africa? Constitutional Engineering in a Divided Society, Berkeley: University of California Press.

[6] Horowitz, D. L. (1985). Ethnic Groups in Conflict. Berkeley: University of California Press.

[7] Horowitz, D. L. (1991a). Ethnic Conflict Management for Policymakers. In J. (. Montville, Conflict and Peacemaking in Multiethnic Societies (pp. 115-130). Lexington, MA: Lexington Books.

[8] Horowitz, D. L. (1991b). Making Moderation Pay: The Comparative Politics of Ethnic Conflict Management. In J. (. Montville, Conflict and Peacemaking in Multiethnic Societies (pp. 451-476). Lexington, MA: Lexington Books.

[9] Horowitz, D. L. (1993). Democracy in Divided Societies. Journal of Democracy, 18-38. 


\section{N. Wijegoonawardana}

[10] Knoerzer, S. (1998). Transformation of Muslim Political Identity in Sri Lanka. Culture and Politics of Identity in Sri Lanka. Colombo: International Centre for Ethnic Studies.

[11] Lewis-Beck, M. S. (2000). Economic Determinants of Electoral Outcomes. Annual Review of Political Science $3,183-219$.

[12] Lichbach, M. a. (1997). Comparative Politics: Rationality, Culture and Structure. . New York: Cambridge University Press.

[13] Siriweera, W. I. (1980). Recent Developments in Sinhala-Tamil Relations. Asian Survey, 20(9), 903-913.

[14] Uyangoda, J. (2010). Politics of Political Reform: A Key Theme in the Contemporary Conflict, Chapter 2. In e. C. Orjuela, Power and Politics in the Shadow of Sri Lanka's Armed Conflict. Stockholm: Swedish International Development Agency (SIDA).

[15] Wickramasinhge, N. (1995). Ethnic Politics in Colonial Sri Lanka 1927-1947. New Delhi: Vika Publishing House.

[16] Wilson, A. J. (1988). The break -up of Sri Lanka: the Sinhalese - Tamil Conflict. . UK: C. Hurst Publishers.

[17] Wilson, A. J. (1999). Sri Lankan Tamil Nationalism: Its Origins and Development in the Nineteenth and Twentieth Century's. Canada: UBC Press.

[18] Wilson, A. J. (2000). Sri Lankan Tamil Nationalism: Its Origins And Developments In The Nineteenth and Twentieth centuries.London: Hurst.

[19] Wilson, A. J. (2001). Sri Lankan Tamil Nationalism. New Delhi: Penguin. 